\title{
The Effect of Bank Liquidity and Efficiency on Non-Interest Income with National Income as Variables Moderator
}

\author{
Dadang Agus Suryanto ${ }^{1,2}$, Disman $^{3}$, Nugraha $^{4}$, Ika Putera Waspada ${ }^{5}$, Sugiyanto $^{6}$ \\ 1,3,4,5 Department of Postgraduate Doctoral in FPEB UPI, Indonesia \\ ${ }^{2}$ STIE Ekuitas, Indonesia \\ ${ }^{6}$ Institut Manajemen Koperasi Indonesia, Indonesia \\ agus_suryanto@upi.edu,dadang.agus@ekuitas.ac.id,disman@upi.edu,nugraha@upi.edu, \\ ikaputerawaspada@upi.edu,Ugie@ikopin.ac.id
}

\begin{abstract}
Empirically, non-interest income from banks in Indonesia has increased in the last five years. Apart from being caused by efficiency issues and the level of risk in interest income, the increase in non-interest income was due to the proliferation of electronicbased banking services. In an effort to understand the influence factors on non-interest income, this study examines the effect of market concentration on third party funds, credit market concentration, capital adequacy, bank liquidity, bank efficiency, non-performing loans, leverage, and reference interest rates on noninterest income. In addition, testing the effect of bank and macroeconomic characteristics variables on non-interest income with national income as a moderating variable and the effect of bank and macroeconomic characteristics on non-interest income with inflation as a moderating variable. This research uses descriptive methods and causality. The research was conducted at conventional National Commercial Banks in Indonesia, which is divided into the periodization of the financial crisis era, namely 2006-2011 and postfinancial crisis, namely 2012-2017. The data collection technique used by researchers is the documentation method. The data analysis technique was performed using unbalance panel data regression analysis. The results showed that bank liquidity and bank efficiency had a significant effect.
\end{abstract}

Keywords liquidity, efficiency, fee-based income; national income

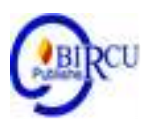

\section{Introduction}

The banking world is inseparable from human life, because all human activities involve finance and require banking facilities. In the banking world, institutions that play an important role are banks, the main function of banks is collecting funds from the public and channeling them back in various forms of investment that can generate profits. Therefore, the bank is a business segment whose activities are largely regulated by the government (Siamat in Tarigan et al, 2020).

Banking as one of the sub-systems of the financial services industry is often considered to be one of the determinants in the economic journey of a country, if the banking industry of a country is slumped, the economy of a country can experience a crisis, so that the banking industry can be used as a barometer of a country's economic stability.

Banking as an institution that has the role of driving and driving the economy of a country, carries out its function as an intermediary institution between surplus economic units and deficit economic units. Therefore, in carrying out its functions, banks face various business 
risks, especially from the credit sector in the form of bad loans which will impact asset quality and increase the NPL ratio which affects the Bank's income and capital (CAR). In line with this, the bank will establish an allowance for credit losses or Loan Loss Provision or allowance for impairment losses (CKPN).

Bank can simply be interpreted as "financial institutions whose main activity is to collect funds from the public and channel them back to the community and provide other bank services (Kasmir, 2004: 11). Furthermore, if viewed from the origin of the occurrence of the Bank, the notion of the bank is a table or place to exchange money. From the description above it can be explained that the Bank is a company engaged in the financial sector, meaning that the banking business is always related to financial matters. (Rosmika et al, 2019)

The banking sector has a real contribution to the economic development of a country. Banks, especially state-owned banks, have an important role in maintaining monetary stability. A stable monetary condition will be able to make development efforts run better because the monetary capacity to finance development is getting stronger. Banks must be able to carry out their functions properly in order to ensure the implementation of development that runs on time and minimal constraints, especially from the monetary side. (Pradata et al, 2020).

Allowance for credit losses is defined as the amount established by a bank to anticipate credit losses. Prior to the improvement of accounting standards, the provision for credit losses was determined using the concept of expected losses, so that banks can accumulate large reserves if the expected losses to be experienced in the future are higher. Banks deliberately accumulated large reserves on the basis of prudence, although the quality of their productive assets was not a worry, this would certainly provide an opening for bank management to practice earnings management. Bank management implements earnings management practices such as income smoothing, or maximizing and minimizing profits to reduce profit fluctuations because investors prefer stable profit growth. When the company has large profits, it will certainly make it difficult for management to increase profits in the following year. Lobo and Yang (2001) who found evidence that the loan loss provision has a positive relationship with income smoothing. If it is related to changes in accounting standards with income smoothing, what is interesting is the impact if there is a change in accounting standards with the flexibility of management in carrying out earnings management. Does it reduce flexibility or even provide a bigger gap, because banks take advantage of discretion in performing income smoothing.

Prior to the implementation of the new financial accounting standards, the establishment of allowance for losses was guided by Bank Indonesia regulations by implementing forwardlooking provisioning where banks could determine the allowance for credit losses even though the losses had not yet occurred. The old standard allowed banks to make judgments (expected loss) in determining impairment losses. As a result, banks have the flexibility in determining the level of impairment losses that are adjusted to the motivation of the bank's management. This is a space that is widely used by bank management to judge their financial statements by applying window dressing.

In order to harmonize financial accounting standards, especially for Indonesian banking and in line with efforts to increase the dicipline market, Bank Indonesia took the initiative to collaborate with the Indonesian Institute of Accountants (IAI) to prepare Financial Accounting Standards adopting International Accounting Standards (IAS) 39 and IAS 32, namely PSK 50 / 55. Both PSAKs, credit as a bank asset are classified as Loans and Receivables, where the valuation is by means of amortized cost, this has the consequence that bank assets in the form of credit will be affected by the cash flow projection of these assets, so that loans are subject to interest below market interest will be discounted to be less than the cost.

The adoption of new accounting standards for banking financial reports or Financial Accounting Standard Statement (PSAK) No.50 and 55 is believed to close the space for 
management to perform window dressing or manipulate bank financial reports for certain purposes. Although the principle based nature of PSAK 50/55 (revised 2006) and emphasizes the concept, its application can provide more space for management to perform earnings management.

It is projected that a strong net interest margin (NIM) will no longer be enjoyed by banks as before. The government's request for banks to reduce loan interest rates will have an impact on the margins received. Banks are expected to diversify their sources of income with this in mind. This can be achieved through cost-based selling or through tightening operating costs through improved performance.

The large net interest margin for banks in Indonesia shows that banks in Indonesia appear to be inefficient. The difference between interest income and interest expense is the NIM. NIM can be defined as the difference between loan interest and savings. The bigger the gap (difference) between interest on debt and deposits, the greater the bank's profits, as seen in general the benefits. The success of an inefficient bank often indicates the level or size of this interest rate spread.

Dabla-Norris \& Floerkemeier (2007) observed that one of the metrics for assessing the efficiency of financial intermediation is the gap (range) between loan and deposit interest rates. To maintain the quality and efficiency of operational operations, each bank strives to manage interest rate spreads. Most of the banks have a NIM rated large, reaching more than five percent, in annual reports released by nine banks listed on the stock exchange, state-owned companies or private companies in the last five years.

The NIM is set at five percent by the Financial Services Authority (OJK) as a limit to banking productivity. This clause refers to those listed as business-based banks (BUKU) 3 and 4, namely banks with a capital of IDR 5 trillion to less than IDR 30 trillion (BUKU 3) and a minimum core capital of IDR 30 trillion (BUKU). 4).

Indonesia's high NIM status reflects the fact that the banking industry in Indonesia is faced with a high level of productivity and risk. Therefore, in the absence of fee-based income, banks need to look for other sources of income. Non-interest income is a form of bank income diversification. Non-interest income is an effort to increase bank income and reduce costs incurred by banks at the same time (DeYoung \& Roland, 2001).

In the last five years, non-interest income from banks in Indonesia has increased empirically. This growth in non-interest income is related to the introduction of an electronicbased banking system, in addition to being exacerbated by productivity problems and the hazardous level of interest income.

The increase in non-interest income that increased during 2013-2017 indicates good bank growth, but the output of bank non-interest income or fee-based income during the Covid-19 pandemic economic crisis is not expected to be the same. last year. This is associated with poor economic results and the retail industry, which tends to be undermined by financial competitors in technology.

Complete income, income from equity participation, tax / profession / retribution and commercial bank administration as of April this year reached Rp 27.53 based on data from the Financial Services Regulator, a slight increase from $\mathrm{Rp} 26.02$ trillion in the same range last year. Meanwhile last year, the total FBI banking as a whole reached Rp. From 82.32 trillion.

Retail consumer purchases, such as cash refills, electronic money refills, mobile wallet refills, and e-commerce payments, are the only FBI outlets that can still be leveraged. Small banks will be under pressure in this case, because the credit card offerings offered by Bank Indonesia will be very good for increasing the use of banks and the FBI. This will be quite complicated, as clients start to reduce their credit card usage. 
In the principle of intermediation, the Bank aims to collect funds from the public or depositors to be distributed to parties in need (Allen \& Santomero, 1998). Apostolic et.al (2009) separate the main operations of banks into three core activities, namely (1) collecting public funds in the form of demand deposits, reserves and deposits, (2) providing financial services, namely transfer payments, capital conversion process, (3) allocation credit to the community. More precisely, the work behavior theory (SCP) notes that it effectively describes a linear correlation between the nature of the banking sector and the behavior of banks in reacting to developing market structures, and consequently bank responses affect bank efficiency. (Neuberger, 1998).

Empirically, from the point of view of the successful behavior structure hypothesis, the study findings on the causes of interest and non-interest income are also being discussed. Maudos \& Solís, (2009) found that interest income in Mexican commercial banking is influenced by variables of market structure, bank performance, and bank size. However, compared to the findings of research on banking in Indonesia, Ariyanto (2011) sees that the

NIM of banking across market systems does not have a major effect, even though banking performance has a major effect on NIM. Manurung (2013) notes that the nature of a bank's business and performance is a determining factor for NIM in commercial banks in Indonesia, and adds that bank scale is a determining factor for NIM.

Nugroho (2012) shows that BOPO has a positive and important effect on bank income. Meanwhile, research by Yuliani (2007) found the opposite, namely OEOI has a negative and substantial effect on bank income. Zeman and Jurca (2008) conducted an analysis in Slovakia which showed that the Slovak banking sector would not be seriously threatened by a substantial decline in GDP growth.

This study aims to examine the effect of liquidity and bank productivity on bank noninterest income with national income as a moderating variable, with a focus on topics, hypotheses and previous studies.

\section{Hypothesis}

H1: There is an effect of bank liquidity on non-interest income

$\mathrm{H} 2$ : There is an effect of bank efficiency on non-interest income

H3: National income is able to modify the effect of bank liquidity and bank efficiency on noninterest income

\section{Research Methods}

The main objective of this research is to conduct an empirical study of the evolution of the structure of bank income in terms of bank characteristics and macroeconomic aspects. In line with the research objectives, researchers used two methods, namely descriptive methods and causality. Kothari (2004) explains that a descriptive approach is an approach that seeks to explain the empirical fact picture of the object under study based on the research data obtained. While causality research is a research approach that seeks to explain the causal relationship of the variables under study.

Bank Liquidity (LDR) is a bank's ability to pay back withdrawals made by depositors by relying on credit channeled as a source of liquidity. Bank liquidity is determined using the Loan to Funding Ratio (LFR) parameter which is formulated as follows:

$$
\begin{aligned}
& \text { LFR }=\frac{\text { Total Credits }}{\text { Total Third Party Funds }+} \\
& \text { Securities }
\end{aligned}
$$


Bank Efficiency (BOPO) is a measure of the level of efficiency and ability of a bank in carrying out its operational activities. The efficiency of a bank is determined using the Operational Cost per Operating Income (BOPO) parameter which is formulated as follows:

$$
\mathrm{BOPO}=\frac{\text { Operating costs }}{\text { Operating Income }}
$$

GDP is the market value of all goods and services produced by a country in a certain period. PDB is determined by the following formulation:

$\mathrm{PDB}=\mathrm{C}+\mathrm{G}+\mathrm{I}+(\mathrm{X}-\mathrm{M})$

Information:

GDP $=$ Gross domestic product value

$\mathrm{C} \quad=$ Household consumption

G. = Government consumption

I $\quad=$ Investment

$\mathrm{X}=$ Export

$\mathrm{M} \quad=$ Import

For the purposes of inferential statistical calculations, the GDP variable is transformed into the natural logarithmic value or Ln PDB. The dependent variable in the study is NonInterest Income (NOII). Non-interest income is a comparison of non-interest income to total bank income (DeYoung \& Rice, 2004; Engle, Moshirian, Sahgal, \& Zhang, 2014; Hahm, 2008; Maudos \& Solís, 2009; Yuwana, Kakinaka, \& Miyamoto, 2012). Based on this explanation, non-interest income is formulated as follows:

$$
\text { NOII }=\frac{\text { Non Interest Income }}{\text { Total income }}
$$

This research focuses on conventional National Commercial Banks in Indonesia which are divided into periods of the financial crisis era, namely 2006 - 2011 and post financial crisis, namely 2012 - 2017.

The data collection technique used by researchers is the documentation method. In accordance with the objectives and empirical research model proposed in this study, the data analysis technique was performed using unbalance panel data regression analysis. The main consideration in selecting the unbalance panel regression is because the researcher wants to obtain accurate periodic research results according to the existing conditions of national commercial banks in Indonesia based on the incidence of financial crises that hit banks in Indonesia.

\section{Result and Discussion}

The probability value of the influence of the LDR variable on the FBI variable is 0.0000 . When compared with alpha levels of $1 \%, 5 \%$, and $10 \%$, it appears that the probability of the resulting regression is below all alpha values which means there is sufficient evidence to reject H0. In other words, bank liquidity has a significant effect on fee-based income, it is acceptable. In addition, the regression coefficient shows a negative sign, which means that the effect of bank liquidity on fee-based income is inversely related. 
The probability value of the influence of the BOPO variable on the FBI variable is 0.0000 . When compared with alpha levels of $1 \%, 5 \%$, and $10 \%$, it appears that the probability of the resulting regression is below all alpha values which means there is sufficient evidence to reject H0. In other words, bank efficiency has a significant effect on fee-based income, it is acceptable. In addition, the regression coefficient shows a negative sign, which means that the effect of bank efficiency on fee-based income is inversely related.

The probability value of the influence of the LDR variable on the FBI variable as moderated by PNB is 0.0000 . When compared with alpha levels of $1 \%, 5 \%$, and $10 \%$ it appears that the probability of the resulting regression is below all alpha which means sufficient evidence to reject H0. In other words, bank liquidity has a significant effect on fee-based income which is moderated by the national income per capita, which is acceptable. In addition, the regression coefficient shows a positive sign, which means that the effect of bank liquidity on fee-based income, which is moderated by national income per capita, is directly proportional.

The probability value of the influence of the BOPO variable on the FBI variable as moderated by PNB is 0.0000 . When compared with alpha levels of $1 \%, 5 \%$, and $10 \%$ it appears that the probability of the resulting regression is below all alpha, which is sufficient evidence to reject H0. In other words, bank efficiency has a significant effect on fee-based income which is moderated by the national income per capita, which is acceptable. In addition, the regression coefficient shows a positive sign, which means that the effect of bank efficiency on fee-based income, which is moderated by national income per capita, is directly proportional.

Damayanti and Savitri (2012) conducted a study in Indonesia during the 2005-2009 period which showed that the results of deposit growth and the loan to deposit ratio (LDR) showed no positive and insignificant effect on bank income. Yuliani (2007) who shows that an increase in LDR under normal conditions can increase bank non-interest income.

Pratiwi (2012) conducted a study in Indonesia which showed the BOPO and NPF variables had a negative and significant effect on the income of Islamic Commercial Banks. Ummah \& Suprapto (2015) the BOPO variable has a negative and significant effect on bank non-interest income. The results of research conducted by Jamilah (2016) show that BOPO has a negative effect on mudharabah financing. Ningrum's research (2017) conducted research in Indonesia that OEOI had a negative and significant effect on the income of Islamic Banking in 2012-2015.

O'Donnell, CJ, \& Van Der Westhuizen, G. (2002) conducted a study in South Africa showing that liquidity is the dominant factor in bank non-interest income. Hou, et., $\mathrm{Al}$ (2018) conducted research in China during the 1996-2015 period showing the results that liquidity had an influence on bank performance and earnings.

Research Thalib (2013) conducted research in Indonesia on 25 commercial banks during the 2008-2013 period that bank intermediation as measured by LDR affects profitability, secondly, capital structure affects profitability, third, bank efficiency affects profitability. The fourth conclusion is that bank capital as measured by the Capital Adequacy Ratio has an effect on profitability, and the five credit risks have an effect on profitability. The LDR variable, Capital Capital Structure has a positive effect, while the Efficiency variable (OEOI) and risk (NPL) have a negative effect.

Achmad (2003) if the amount of credit given is smaller than the collected funds, then the excess funds can be placed in other useful things with less risk. The higher the value of the Loan Deposit Ratio (LDR), the lower the liquidity capacity of the bank concerned so that the possibility of a bank in a problematic condition will be greater, conversely the lower the Loan Deposit Ratio (LDR) ratio indicates the lack of effectiveness of the bank in extending credit so that the bank's opportunity is lost. to make a profit. 
Research conducted by Rana, Hossain and Rekha (2016) in Bangladesh shows that liquidity affects the income of Islamic banks, but has no effect on conventional banks. His research states that the performance of Islamic banks is better than conventional banks. In addition, there is another study in Ethiopia conducted by Bono (2020) which shows that liquidity has an impact on bank non-interest income.

Kesowo, Kuncoro and Suharjono (2002) show that BOPO has a positive and significant effect on bank income. Meanwhile, research conducted by Yuliani (2007), Rinawan (2009) showed the opposite result, namely BOPO had a negative and significant effect on bank income.

Research in developed countries and emerging markets conducted by Mohd Zaini Abd Karim and Sallahudin Hassan (2010) conducted a study in Malaysia and Singapore showing the results that Bank Efficiency and Cost Efficiency had a negative and significant effect on bank income. Abiola and Olausi (2014) also conducted a study in Nigeria for the period 20052011 which found that credit risk as stated by the NPL ratio had a positive and significant effect on bank income.

Research patterns in emerging countries and in Indonesia indicate research inconsistencies, both influencing and non-influential, this condition is because in general banks are companies that have fast liquidity, so this is not a factor that consistently affects bank noninterest income.

The pattern in developed and emerging market countries, bank efficiency (BOPO) consistently has a negative effect on bank income, however in Indonesia it shows inconsistent results where the effect of bank efficiency (BOPO) can be positive or negative on bank noninterest income. Research patterns in emerging countries and in Indonesia indicate research inconsistencies, both influencing and non-influential, this condition is because in general banks are companies that have fast liquidity, so this is not a factor that consistently affects bank noninterest income.

The pattern of influence from various countries, it can be consistently understood that national income can be a moderating variable for bank and macroeconomic characteristics variables on bank non-interest income.

\section{Conclusion}

Research patterns in emerging countries and in Indonesia indicate research inconsistencies, whether influential or not. The pattern in developed and emerging market countries, bank efficiency and bank liquidity consistently have a negative effect on bank income, however in Indonesia it shows inconsistent results where the effect of bank efficiency and bank liquidity can be positive or negative on bank non-interest income. National income is able to be a moderating variable for bank characteristics and macroeconomic variables on bank non-interest income.

\section{References}

Abd Karim, M. Z., Chan, S. G., \& Hassan, S. (2010). Bank efficiency and non-performing loans: Evidence from Malaysia and Singapore. Prague Economic Papers, 2(1).

Abiola, I., \& Olausi, A. S. 2014. "The Impact of Credit Risk Management on the Commercial Banks Performance in Nigeria". International Journal of Management and Sustainability, 3(5): 295-306.

Achmad, S. 2003. Ekonomi Perbankan. Jakarta: STIE Gunadarma. 
Allen, F., \& Santomero, A. M. (1998). The Theory of Financial Intermediation. Journl of Banking \& Finance, 21, 1461-1485.

Apostolik, R., DONOHUE, C., \& WENT, P. (2009). Foundations of Banking Risk: An Overview of Banking. Banking Risks, and Risk-Based Banking Regulation, Hoboken/New Jersey.

Ariyanto, T. (2011). Faktor Penentu Net Interest Margin Perbankan Indonesia. Finance and Banking Journal, 13(1), 34-46.

Bono, Z. B. (2020). Determinants of Bank Liquidity and Its Impact on Bank Profitability in Ethiopia. Journal of Modern Accounting and Auditing, 16(6), 254-263.

Dabla-Norris, E., \& Floerkemeier, H. (2007). Bank Efficiency and Market Structure: What Determines Banking Spreads in Armenia? (No. 07). New York, United State of America.

Damayanti, P., \& Savitri, D. A. M. (2018). Analisis Pengaruh Ukuran (Size), Capital Adequacy Ratio (Car), Pertumbuhan Deposit, Loan to Deposit Rasio (Ldr), Terhadap Profitabilitas Perbankan Go Public Di Indonesiatahun 2005-2009. Jurnal Ilmu Manajemen Dan Akuntansi Terapan (JIMAT), 3(2), 45-54.

DeYoung, R., \& Rice, T. (2004). Noninterest Income and Financial Performance at U.S. Commercial Banks. The Financial Review, 39, 101-127.

DeYoung, R., \& Roland, K. P. (2001). Product Mix and Earning Volatility at Commercial Banks: Evidence frim a Degree of Leverage Model (No. WP-99-6). Chicago, United States of America.

Engle, R., Moshirian, F., Sahgal, S., \& Zhang, B. (2014). Banks Non-Interest Income and Global Financial Stability.

Hahm, J. (2008). Determinants and Consequences of Non-Interest Income Diversification of Commercial Banks in OECD Countries. Journal of International Economic Studies, 12(1), 3-32.

Hidayat, A., \& Sunarsi, D. (2020). Faktor-Faktor Yang Mempengaruhi Dana Pihak Ketiga Dan Dampaknya Terhadap Profitabilitas (Survey Pada Bpr Syariah Di Jawa Barat Tahun 2014-2017). Jurnal Proaksi, 7(1), 54-65.

Hou, X., Li, S., Li, W., \& Wang, Q. (2018). Bank diversification and liquidity creation: Panel Granger-causality evidence from China. Economic Modelling, 71, 87-98.

Jamilah, J. (2016). Faktor-faktor yang Mempengaruhi Pembiayaan Mudhrabah Pada Bank Umum Syariah di Indonesia. Jurnal Ilmu dan Riset Akuntansi, 5(4), 1-20.

Jurča, P., \& Zeman, J. (2008). Macro stress testing of the Slovak banking sector (No. 1/08). Working Paper.

K Nufus, H Supratikta, A Muchtar, D Sunarsi. (2020). Analysis of Financial Performance: Case Study of PT. X Employee Cooperative. Utopía Y Praxis Latinoamericana. Vol. 25. Pages 429-444

Kothari, C. R. (2004). Research Methodology: Methods and Techniques (Second Revised Edition). New Delhi: New Age International, Ltd.

Lobo, G. J., \& Yang, D. H. (2001). Bank managers' heterogeneous decisions on discretionary loan loss provisions. Review of Quantitative Finance and Accounting, 16(3), 223-250.

Manurung, A. H. (2013). Net Interest Margin : Bank Publik di Indonesia. Jakarta, Indonesia.

Masud Rana, M., Hossain, K., \& Rekha, R. S. (2016). Profitability and liquidity of conventional banking and Islamic banking in Bangladesh: A comparative study. IJAR, 2(9), 318-327.

Maudos, J., \& Solís, L. (2009). The determinants of net interest income in the Mexican banking system: An integrated model. Journal of Banking \& Finance, 33(10), 1920-1931. 
Maudos, J., \& Solís, L. (2009). The Determinants of Net Interest Income in the Mexican Banking System : An Integrated Model. Journal of Banking and Finance, 33(10), 19201931.

Neuberger, H. (1998). Exactly massless quarks on the lattice. Physics Letters B, 417(1-2), 141144.

Ningrum, A., \& Imronudin, S. (2017). Pengaruh kondisi Ekonomi, NPR, FDR Dan BOPO Terhadap Profitabilitas Perbankan Syariah Di Indonesia Tahun 2012-2015 (Doctoral dissertation, Universitas Muhammadiyah Surakarta).

Nugroho, V. (2012). Pengaruh CAMEL Dalam Memprediksi Kebangkrutan Bank. Jurnal Akuntansi, 16(1), 145-161.

O'Donnell, C. J., \& Van Der Westhuizen, G. (2002). Regional comparisons of banking performance in South Africa. South African Journal of Economics.

Pratiwi, D.D. (2012). Pengaruh CAR, BOPO, NPF dan FDR Terhadap Return on Asset (ROA) Bank Umum Syariah (Studi Kasus pada Bank Umum Syariah di Indonesia Tahun 2005 -2010. Semarang: Fakultas Ekonomi dan Bisnis.

Pradata. Y, et al. (2020). Determinants of Savings and Community Loans in Ngawi District, 2010 - 2018 A Macro Economic Approach. Budapest International Research and Critics Institute-Journal (BIRCI-Journal). P. 1506-1517.

Rosmika, T,. et al. (2019). The Role of BRI Bank Medan Perjuangan Unit for Customer's Households, Indonesia. Budapest International Research and Critics Institute-Journal (BIRCI-Journal). P. 363-374.

Suhartono, A., Jati, W., \& Sunarsi, D. (2019). Pengaruh Earning Per Share Dan Return On Asset Terhadap Harga Saham Pada PT. Bank Negara Indonesia Tbk Periode 2009-2018. Jurnal Manajemen, Bisnis dan Organisasi (JUMBO), 3(3), 182-194.

Tarigan, N, et al. (2020). The Effect of Employee Competence on Increasing Employee Motivation in Sumut Bank of Sharia Unit, North Sumatera. Budapest International Research and Critics Institute-Journal (BIRCI-Journal). P. 858-867

Thalib, D. (2013). Intermediasi, struktur modal, efisiensi, permodalan dan risiko terhadap profitabilitas bank. Sumber, 13(6), 2014.

Ummah, F. K., \& Suprapto, E. (2015). Faktor-Faktor yang Mempengaruhi Profitabilitas pada Bank Muamalat Indonesia. Jurnal Ekonomi dan Perbankan Syariah, 3(2), 1-24.

Yuliani, Y. (2007). Hubungan efisiensi operasional dengan kinerja profitabilitas pada sektor perbankan yang go publik di Bursa Efek Jakarta. Jurnal Manajemen dan Bisnis Sriwijaya, 5(10), 15-43.

Yuliani, Y. (2007). Hubungan efisiensi operasional dengan kinerja profitabilitas pada sektor perbankan yang go publik di Bursa Efek Jakarta. Jurnal Manajemen dan Bisnis Sriwijaya, 5(10), 15-43.

Yusni Nuryani, Denok Sunarsi. (2020). The Effect of Current Ratio and Debt to Equity Ratio on Deviding Growth. JASa (Jurnal Akuntansi, Audit dan Sistem Informasi Akuntansi) Volume 4, Issue 2, Pages 304-312

Yuwana, W., Kakinaka, M., \& Miyamoto, H. (2012). Bank Risk and Non-Interest Income Activities in The Indonesian Banking Industry. Journal of Asian Economics, 23(4), 335343. https://doi.org/10.1016/j.asieco.2012.03.008 